\title{
correspondence
}

\section{Human ingenuity is wasted on nuclear power}

SiR,--I rather hoped that "nuclear nonsense" might draw a response from UKAEA. It is not nonsense that fast reactors produce 60 times more energy than thermal reactors. I said in my original letter (13 September, page 98 ) that it might be true in 200 years' time. Cutts and Smith (18 October, page 522) admit that it could not come about until after all thermal reactors had been replaced by fast reactors, and that on the best figures UKAEA could produce the ratio would only be 1.7 by 2020; so as they do not give a figure of their own, I take it that 200 years is not unreasonable.

What is nonsense is the use of this hypothetical long term ratio of 60 as an argument for developing fast breeder reactors now. It is all the more nonsensical because Granger and Merrick showed that even a delay in starting a fast breeder programme of as much as 30 years would be rapidly made up. because the main limiting factor is the production of plutonium by thermal reactors. This is implicitly admitted by Cutts and Smith, because having predictably taken my "nuclear nonsense" to refer to the 60 times ratio, rather than Smith's use of it to support the development of fast breeder reactors, they then drop this argument and concentrate on lauding the possibility of eventually reducing uranium imports to zero. On this basis coal would seem to be a clear winner for the medium term, and the long term superiority of conservation plus solar energy over both hardly needs demonstrating.

It is an amazing paradox that nuclear scientists and technologists - even Alvin Weinberg (4 October, page 335) - can claim that human ingenuity is so great that it can deal successfully with all the problems which are associated with Three Mile Island and the 'China Syndrome', in a world dotted with nuclear reactors and repositories of highly radio-active waste requiring protection for thousands of years, a world in which the use of nuclear energy will inevitably be accompanied by the widest proliferation of nuclear weapons. Yet when faced with the job of utilising just one hundredth of one per cent of the energy showered on us by the only safe nuclear power plant - the Sun - human ingenuity flies out of the window, and only the difficulties can be seen. Yet this latter use of human ingenuity is the only one which offers even a glimmer of hope for the future of mankind.

Yours faithfully,

J. W. JEFFERY

Birkbeck College, University of London, UK.

\section{Aflatoxin $B_{1}$ in barley in the UK}

SIR, - In the United Kingdom in the early 1960 s a link between the death of 100,000 turkey poults and the fungus Aspergillus flavus was recorded. Further studies identified the toxic entity of the fungus to be aflatoxin $\mathbf{B}_{1}$, produced in imported groundnut. Further research led to the detection of aflatoxin in many animal and human feeds imported into the United Kingdom, e.g. walnut, pistachio, maize, cotton seed, etc.

Though $A$. flavus has been isolated in the

UK, it has been thought either that strains are not capable of producing aflatoxin $\mathrm{B}_{1}$, or that the substrate and conditions are not conducive to aflatoxin $B_{1}$ production. In June of this year, however, a farmer requested advice from Microbiology Department of the Ministry of Agriculture, Wales on the health risk to himself or his stock from mouldy barley. Enquiries found the barley had been treated with commercial propionic acid at an inadequate application level. Further laboratory examinations showed the mould to be Aspergillus flacus $\left(5 \times 10^{7}\right.$ prepagules $/ 8$ barley), while mycotoxin examination gave a level of $125 \mu \mathrm{g}$ aflatoxin $\mathrm{B}_{1} / \mathrm{kg}$ barley.

The detection in a home grown cereal of aflatoxin must be regarded with some concern, because of its known carcinogenic and toxic properties. Also, questions must be asked as to the significance of a chemical additive.

Additional studies are to be carried out to place this finding in perspective. We intend to study $A$. flavus isolates from soil and grain in Wales, for their ability to grow in varying concentration of propionic acid, and also, to assess such isolates for aflatoxin $B_{1}$

production. The results should help to clarify whether this incident is an isolated case or part of a greater problem.

$$
\text { Yours faithfully, }
$$

Welsh Office, Aberystwyth, UK.

A. Hackinc N. R. BIGGS

\section{Cooperation with the USSR}

SIR, - I have read the letter from Lee Lorch (13 September, page 98) with great concern. He does not seem to realize that cooperation must be two-sided; to be accepted as an equal partner, the Soviet Union must treat all its nationals on an equal footing.

Admittedly, the West may lose as much as the USSR by reduction of cooperation. But what other way is there of protesting against the way that the USSR is treating its Jewish scientists?

$$
\text { Yours faithfully, }
$$

H. LIPSON

University of Manchester Institute of Science and Technology, UK.

\section{Wartime research on nitrogen mustard}

SIR, - Thirty seven years ago the late Major $J$. M. Moore of the USA and I carried out classified experiments on the influence of nitrogen mustard - then a secret compound - on the bone marrow stem cells. Dameshek ${ }^{1}$, Gilman $^{2}$ and Harrison ${ }^{3}$ have commented on work prior to 1945 as being classified but important in the evolution of the treatment of leukaernia and cancer. Colleagues in Melbourne have suggested that for historical reasons we should have our work carried out in 1942 declassified and published.

During the first world war mustard gas exposure in man was found to be associated with leukopaenia. This was believed to be due to superadded infection; it was not recognised that it was due to a chemical effect on the bone marrow.

In 1942 we tested the effect of nitrogen mustard on the bone marrow. We selected guinea pigs and compared the cellular distribution in bone marrow in a series of control animals against that of a series of similar animals exposed to the vapour of nitrogen mustard. Red marrow from the upper end of the tibia was examined. We found both the ceils of the myeloblast series and the lymphoblast series were highly significantly reduced in numbers. This information was supplied to both the Ministry of Supply, London and also to Washington at that time. It is interesting to note that at that time much doubt was expressed that lymphocytes actually developed in bone marrow. This work was done in my laboratory at the University of Melbourne.

The Australian Defence Research Laboratory recently told me that there was no difficulty in obtaining security clearance for this work which was now common knowledge - but they were not able to find the documents recording the research of the "Gorrill" chemical warfare research team.

Our experiments on chemical warfare agents were essential to the war effort both owing to the capability of the Japanese in chemical warfare and the world ignorance of the precise effect of these agents under tropical conditions as applied to New Guinea. Unfortunately some years after the war, a directive was made that all documents relating to this work by the

"Gorrill team" - later under the direction of another commanding officer - were to be destroyed. The senior official who destroyed them told one of us he though he might have been destroying significant scientific material. Under security wartime arrangements neither of us had copies of this document.

$$
\text { Yours faithfully, }
$$

E. R. TRETHEWIE

Walter and Eliza Hall Institute of Medical Research, Victoria, Australia.

1. Dameshek Blood, 4, 338, (1949)

2. Gilman Science, 103,140, (1946)

Text Book of Medicine, Harrison, p. 1787 (McGraw-Hilt, New York, 1977)

\section{Obstructionists in environment clothing}

SIR,-After its sincere start, "The end of the age of Aquarius?" (20 September, page 168) has been brought about in part by the duplicity of some so-called

"environmentalists"', who are, in fact, merely obstructionists. The writer personally investigated an attempt by such a group to include in the Organic Act, governing the US Bureau of Land Management, the setting aside of several square miles of rich coal lands in southern Utah as a sanctuary for the.sideblotched uta, Uta stansburyensis. This small, brown lizard, with its subspecies, is common in suitable habitat over most of the Desert Southwest, from western Colorado to eastern California and is by no means in danger of extinction. Only the alertness of a US Senator from Nevada thwarted the move.

Even the discovery of the snail darter as an endangered species appears to have been based on an effort to block the construction of the Tellico dam, and not vice versa. Thus do the over-zealous and ulterior motivated subvert worthy endeavour, with the result that the efforts of the reasonable and sincere are eventually largely nullified. Yours faithfully, S. Ralph Austin 